\title{
Micheliniidae and Cleistoporidae (Anthozoa, Tabulata) from the Devonian of Spain
}

\author{
ANDREAS MAY
}

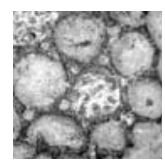

\begin{abstract}
The present article describes five different tabulate coral species of the families Micheliniidae and Cleistoporidae from the Emsian and Eifelian of various localities in northern and central Spain. The species Pleurodictyum elisabetae sp. nov. is erected. Michelinia guerangeri (Milne-Edwards \& Haime, 1851) and Cleistopora smythi Le Maître, 1952 are described for the first time from Spain. The Spanish fauna's biogeographical relationships to France, Germany and northern Africa are very close. The Spanish fauna belongs to the Ibarmaghian Domain of the North Gondwana Province. The biostratigraphical value of the species found is very limited. Key words: Anthozoa, biogeography, Devonian, systematics, tabulate corals, Spain.
\end{abstract}

MAY, A. 2006. Micheliniidae and Cleistoporidae (Anthozoa, Tabulata) from the Devonian of Spain. Bulletin of Geosciences 81(3), 163-172 (1 figure). Czech Geological Survey, Prague. ISSN 1214-1119. Typescript received May 29, 2006; accepted in revised form July 26, 2006; issued September 30, 2006.

Andreas May, Saint Louis University - Madrid campus, Avenida del Valle 34, E-28003 Madrid, Spain; maya@madrid.slu.edu

Knowledge of Devonian tabulate corals in Spain is very incomplete, and few modern publications about them are available. The favositids have been examined by Oekentorp (1975), and similar work for the thamnoporids has been done by May (1993c, 1995). Fernández-Martínez (1999) published a paper on heliolitids. Other publications deal with members of the genus Parastriatopora from Spain (Tourneur \& Fernández-Martínez 1991, Lafuste et al. 1992, Fernández-Martínez \& Tourneur 1993, May 1993c, 2005).

Little is known about Spanish representatives of the Micheliniidae and the closely related Cleistoporidae, two families of favositid tabulates that lived far away from reefs. Oekentorp (1975, fig. 3) reports Pleurodictyum problematicum Goldfuss, 1829 from the Emsian of the Asturian coast. Crousilles et al. (1978) present "Michelinia" homofavosa (Le Maître, 1952) from the Lower Devonian of the Cordoba province. Lafuste et al. (1993) show "Ligulodictyum" n. sp. from the upper Gedinnian of Asturias. Plusquellec (1993) describes Procterodictyum polentinensis Plusquellec, 1993 from the Emsian of the Cantabrian Mountains. García-Alcalde \& Soto (1999, pl. 1, figs 1-4) report Procteria (Granulidictyum) granulifera (Schlüter, 1889) and Kerforneidictyum kerfornei (Collin, 1912) from the Eifelian/Givetian boundary beds of Aleje (Provincia León). Finally, Fernández-Martínez \& Plusquellec (2006) describe Praemichelinia steli Fernández-Martínez \& Plusquellec, 2006 from the upper Emsian of Colle (Provincia León) in the Cantabrian Mountains.
The lack of information from Spain is especially problematic considering that the families Micheliniidae and Cleistoporidae are well investigated in the neighbouring regions of France (Plusquellec 1965, 1970, 1973, 1976, 1993, Le Menn et al. 1976), Germany (Fuchs \& Plusquellec 1982, Byra 1983, Birenheide 1985, Birenheide et al. 1989, Plusquellec \& Jahnke 1999) and northern Africa (Le Maître 1952, Lafuste et al. 1993, Plusquellec et al. 1993, Boumendjel et al. 1997, Plusquellec 1998). Consequently, the finding of several specimens belonging to the Micheliniidae and Cleistoporidae from various Spanish localities in the collections of the Museo Geominero in Madrid is of particular interest. The main purpose of this investigation is to increase the knowledge of Spanish Devonian tabulate corals by describing this important material. Furthermore, particular attention is drawn to the palaeobiogeographical implications of these findings, as little is known about the palaeobiogeographical relations of the Spanish Micheliniidae and Cleistoporidae.

\section{Materials and methods}

All the material investigated belongs to the historical collections housed in the Museo Geominero in Madrid. Consequently, the information on the localities and the stratigraphical position is not as detailed as is now customary. Except for the Procteria (Granulidictyum) granulifera (Schlüter, 1889) 
from the upper Eifelian of Polentinos (stock No. 496D), the stratigraphical information given by the database of the museum is invariably "Emsian/Couvinian". However, in some cases data from the literature allowed the further restriction of their stratigraphical position. Because these specimens are part of the historical collections and are very small, it was not possible to make thin sections in the cases where the skeleton was preserved.

The systematic classification follows Hill (1981) and Birenheide (1985).

\section{Systematic description}

Class Anthozoa Ehrenberg, 1834

Subclass Tabulata Milne-Edwards \& Haime, 1850

Order Favositida Wedekind, 1937

Family Micheliniidae Waagen \& Wentzel, 1886

\section{Genus Pleurodictyum Goldfuss, 1829}

Type species. - Pleurodictyum problematicum Goldfuss, 1829.

Diagnosis and occurrence. - See Birenheide (1985, p. 92).

\section{Pleurodictyum problematicum Goldfuss, 1829}

Figure 1A, B

* 1829 Pleurodictyum problematicum Goldfuss, Goldfuss, p. 113, pl. 38, fig. 18a-g, pl. 160, fig. 19a-d.

1875 Pleurodyctyum problematicum Gold. - Mallada, p. 81, pl. 13, fig. 1.

non 1948 Pleurodictyum problematicum Gold. - Hernández Sampelayo, pp. 28-29, pl. 7, figs 4, 5, pl. 8, fig. 1.

1965 Pleurodictyum problematicum Goldfuss, 1826. Plusquellec, pp. 7-10, pl. 1, figs 1, 4 (see for further synonymy).

1975 Pleurodictyum problematicum Goldfuss, 1829. - Oekentorp, fig. 3.

1982 Pleurodictyum problematicum Goldfuss, 1829. Fuchs \& Plusquellec, pp. 5-19, figs 4-20, pls 1-3 (see for further synonymy).
1985 Pleurodictyum problematicum Goldfuss, 1829. - Birenheide, p. 93, pl. 34, fig. 1 (see for further synonymy).

2003 Pleurodictyum problematicum. - Botquelen, pl. 12, fig. 10.

Neotype and diagnosis. - See Fuchs \& Plusquellec (1982, p. 5).

Material. - Two coralla in steinkern preservation from the "Emsian/Couvinian" of Almaden (Provincia Ciudad Real) (stock No. 12D and 1330D).

Description. - The smaller corallum is $20 \mathrm{~mm}$ in diameter, the larger $30 \mathrm{~mm}$. Both coralla show the typical characteristics of Pleurodictyum. The calices are $2-3 \mathrm{~mm}$ in diameter (mostly $2.5-3.0 \mathrm{~mm}$ diameter) and 4-6 $\mathrm{mm}$ in depth (mostly $5 \mathrm{~mm}$ depth). Mural pores are large and numerous. Impressions of short septal spines are ordered in vertical rows. There are tubes of Hicetes Clarke, 1908 in the centre of both coralla.

Remarks. - The Spanish material correlates very well with the descriptions of Pleurodictyum problematicum Goldfuss, 1829 given by Plusquellec (1965), Fuchs \& Plusquellec (1982) and Birenheide (1985).

Mallada (1875) describes Pleurodictyum problematicum from four different localities in Spain. Oekentorp (1975, fig. 3) includes a picture of it from the lower Emsian of the Asturian coast. Botquelen (2003) includes Pleurodictyum problematicum from the lower Emsian of the Armorican Massif (France).

Hernández Sampelayo (1948) features Pleurodictyum problematicum from the Lower Devonian of the Western Sahara. The material of Hernández Sampelayo (1948, pl. 7, figs 4,5), which is stored in the palaeontology collection of the Museo Geominero (Madrid) under stock No. 1790X, belongs to the genus Procteria. The corallum figured in pl. 8, fig. 1 has not been found; however, it is very doubtful that it pertains to Pleurodictyum problematicum.

Occurrence. - Pleurodictyum problematicum Goldfuss, 1829 is widespread in the Pragian and Emsian (mainly in the lower Emsian) of Germany, Belgium, France, Spain

Figure 1. • A - Pleurodictyum problematicum Goldfuss, 1829, stock No. 1330D, Emsian/Eifelian of Almaden (Provincia Ciudad Real). • B Pleurodictyum problematicum Goldfuss, 1829, stock No. 12D, Emsian/Eifelian of Almaden (Provincia Ciudad Real). $\bullet$ C - Pleurodictyum elisabetae sp. nov., holotype, stock No. 13D, Emsian/Eifelian of Tramacastilla de Tena (Provincia Huesca). $・$ D - Pleurodictyum elisabetae sp. nov., paratype, stock No. 14D, Emsian/Eifelian of Tramacastilla de Tena (Provincia Huesca). E - Procteria (Granulidictyum) granulifera (Schlüter, 1889), stock No. 496D, upper Eifelian of Polentinos (Provincia Palencia). F-H - Michelinia guerangeri (Milne-Edwards \& Haime, 1851), stock No. 1111D, upper Emsian of Colle (Provincia León). $\bullet \mathrm{F}$ - corallites in longitudinal section. $\bullet \mathrm{G}$ - oral view showing calices. $\bullet \mathrm{H}$ - lateral view showing growth wrinkles. $\bullet \mathrm{I}-$ Procteria (Granulidictyum) granulifera (Schlüter, 1889), stock No. 1516D, upper Emsian of Colle (Provincia León). • J-K - Cleistopora smythi Le Maître, 1952, stock No. 41D, Emsian/Eifelian of Las Peñotas (Provincia León). $\bullet J$ - oral view showing calices. $\bullet \mathrm{K}$-longitudinal section. Scale bar represents $10 \mathrm{~mm}$. 

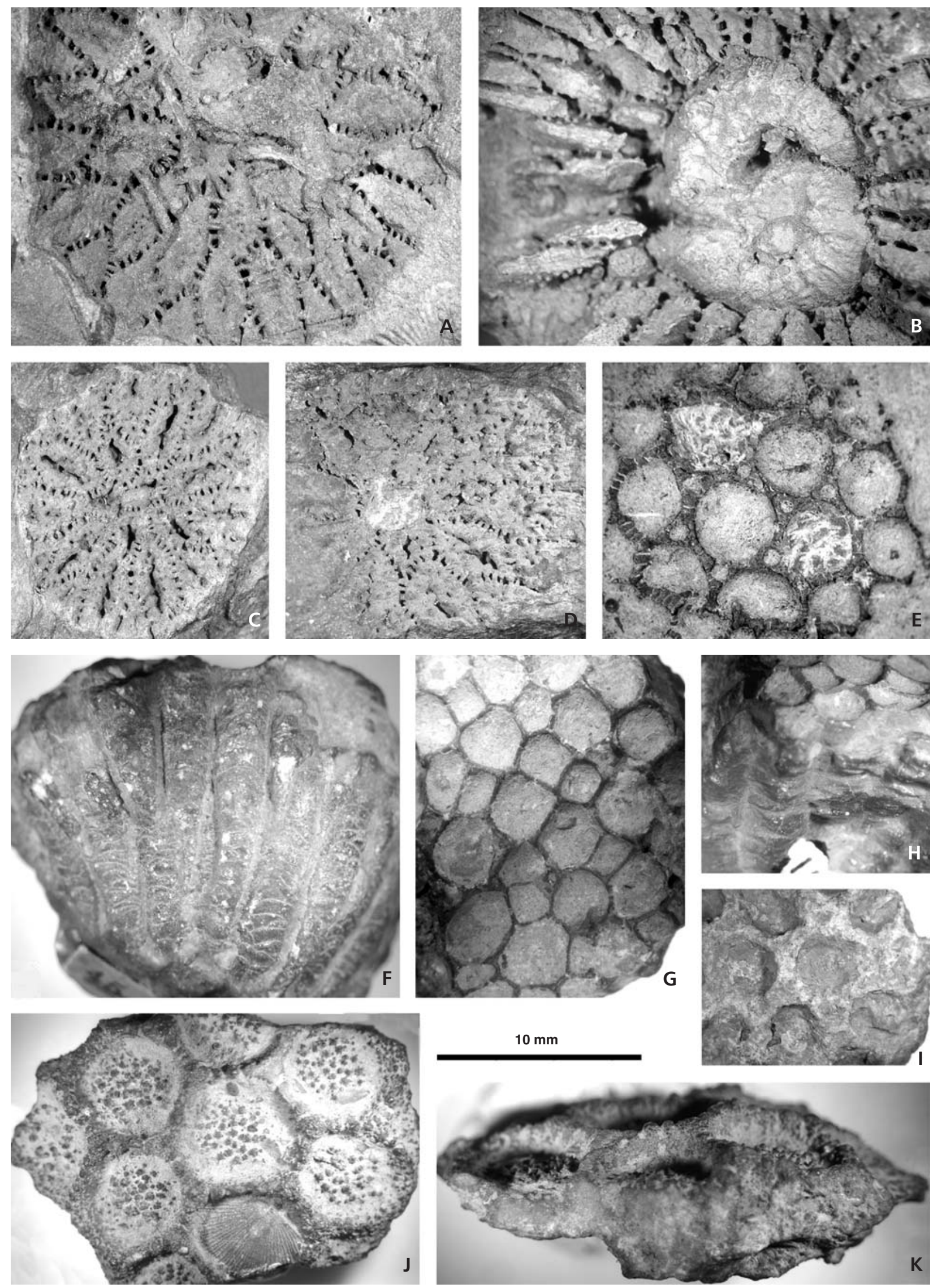
and northern Africa (Plusquellec 1965, Fuchs \& Plusquellec 1982, Birenheide 1985). The material described here from the Emsian/Eifelian of Central Spain fits well with the known distribution of the species.

\section{Pleurodictyum elisabetae sp. nov. Figure 1C, D}

Holotype. - Figure 1C, stock No. 13D, Museo Geominero (Madrid).

Paratype. - Figure 1D, stock No. 14D, Museo Geominero (Madrid).

Type horizon and locality. - Both holotype and paratype come from the "Emsian/Couvinian" of Tramacastilla de Tena (Provincia Huesca).

Material. - Only the holotype and the paratype.

Etymology. - After the present author's daughter, Elisabet.

Diagnosis. - A species of Pleurodictyum with calices of 1.0-2.0 $\mathrm{mm}$ diameter and 4-6 $\mathrm{mm}$ depth. Mural pores are very large (0.2-0.3 mm diameter) and numerous.

Description. - Both coralla are in steinkern preservation, $15 \mathrm{~mm}$ in diameter, and show the typical characteristics of Pleurodictyum. The coralla are flat. The aboral side is not preserved. In the holotype (13D) the calices have a $1.0-1.7 \mathrm{~mm}$ diameter (mostly $1.2-1.3 \mathrm{~mm}$ diameter) and 4-5 $\mathrm{mm}$ depth. In the paratype (14D) the calices are $1.1-2.0 \mathrm{~mm}$ in diameter (mostly $1.5 \mathrm{~mm}$ diameter) and 4-6 mm deep.

New corallites intercalate between the existing ones, giving the corallum a radiating appearance. The internal moulds of the corallites do not show the longitudinal depression that is familiar from several species of Pleurodictyum.

The common wall between the corallites is around $0.3-0.6 \mathrm{~mm}$ thick (with some uncertainty because of difficulties of measuring this distance in steinkern preservation). Mural pores are very large and numerous. They are channel-like, straight or (less commonly) slightly bent. The mural pores are $0.2-0.3 \mathrm{~mm}$ in diameter and $0.3-0.8 \mathrm{~mm}$ apart from each other.

Impressions of short, isolated septal spines are irregularly distributed in the area between the mural pores. The septal spines are less common than the mural pores. In cross-section the septal spines are more or less round and about $0.1 \mathrm{~mm}$ thick. The septal spines are not ordered into vertical rows. Septal ridges do not occur.

No indication of the existence of tabulae could be found. In the centre of both coralla are foreign bodies that we cannot identify unequivocally. They are possibly tubes of Hicetes Clarke 1908.

Remarks. - The material clearly belongs to the genus Pleurodictyum. It shows close similarities to Pleurodictyum problematicum Goldfuss, 1829, but has much smaller corallites. (For example, the calices of $P$. problematicum are $2.5-3 \mathrm{~mm}$ in diameter). In all the literature consulted no comparable species has been described.

The only exception is the description of Pleurodictyum? parvum Dubatolova, 1960 from the Lower Devonian of the Upper Amur Basin (Asian part of Russia) by Dubatolov \& Dubatolova (1969, p. 40, pl. 9, figs 3, 4). Dubatolov \& Dubatolova (1969) report a corallite diameter of 1.0-1.5 mm and wall thickness of 0.2-0.4 mm. These dimensions are consistent with Pleurodictyum elisabetae sp. nov. However, Dubatolov \& Dubatolova (1969, p. 40) state that the mural pores are small. They do not give any measurements, but their figures show that the mural pores in Pleurodictyum? parvum Dubatolova, 1960 are small and unimportant. This is clearly different than Pleurodictyum elisabetae sp. nov. with very large and frequent mural pores. Nevertheless, it is possible that Pleurodictyum elisabetae sp. nov. and Pleurodictyum? parvum Dubatolova, 1960 are related. Unfortunately, all attempts by the author and his colleagues to find the original publication of Pleurodictyum? parvum Dubatolova, 1960 have failed. Consequently, it is probable that the description by Dubatolov \& Dubatolova (1969) is the first description of Pleurodictyum? parvum.

Occurrence. -Pleurodictyum elisabetae sp. nov. is currently known only from the Emsian/Eifelian of Tramacastilla de Tena (Provincia Huesca).

\section{Genus Michelinia De Koninck, 1841}

Type species. - Calamopora tenuiseptata Phillips 1836, sensu De Koninck, 1841.

Diagnosis and occurrence. - See Birenheide (1985, p. 97).

Remarks. - For Michelinia guerangeri (Milne-Edwards \& Haime, 1851) the genus Praemichelinia was erected by Lafuste \& Plusquellec (1980, p. 143), based on some differences in the orientation of the (micro-)lamellae of the microstructure (Lafuste \& Plusquellec 1980, Lafuste \& Plusquellec 1985, pp. 24-25). Birenheide (1985, p. 97) considers Praemichelinia Lafuste \& Plusquellec, 1980 as a junior synonym of Michelinia De Koninck, 1841.

Oekentorp \& Schröder (2001) discuss the differences in the microstructure between Praemichelinia and Miche- 
linia (Protomichelinia), with the result that they interpret the differences as being a result of diagenetic alterations of the microstructure.

Fernández-Martínez \& Plusquellec (2006, pp. 46, 47) justify the validity of the genus Praemichelinia based on details of the microstructure, and state: "In the absence of a convincing demonstration that the morphology, polarity and disposition of the lamellae (and microlamellae) in relation to the median dark line are no more than the result of diagenetic processes, it seems appropriate to accept the validity of the genus Praemichelinia, just as defined by Lafuste \& Plusquellec (1985)" (Fernández-Martínez \& Plusquellec 2006, p. 47). However, Oekentorp (1972, pp. 55-69; 1980, pp. 148-150) uses many examples to demonstrate that these types of (micro-)lamellar microstructures and the orientation of the (micro-)lamellae are the results of diagenetic alterations. That Fernández-Martínez \& Plusquellec (2006) are apparently unaware of these publications is perhaps because they are written in German. Nevertheless, in the " $8^{\text {th }}$ International Symposium on Fossil Cnidaria and Porifera" Oekentorp presents a current discussion of diagenetic alterations of the microstructure of Palaeozoic corals in English, again proving the diagenetic origin of (micro-)lamellar microstructures in corals (Oekentorp 2001, p. 201-207). It is concluded that "Finally, 'microlamellar structures' respectively pseudolamellae and zigzag-patterns are, as proven several times, and again substantiated by observations in Enallophrentis and Procteria, doubtless diagenetic in origin!" (Oekentorp 2001, p. 207).

Based on the investigations of Oekentorp (1972, 1980, 2001), which are confirmed by the present author's own experience with diverse diagenetic alterations of the microstructure in Devonian tabulate and rugose corals (May 1993a, b), the opinions of Birenheide (1985) and Oekentorp \& Schröder (2001) are followed, and Praemichelinia is considered as a junior synonym of Michelinia.

\section{Michelinia guerangeri (Milne-Edwards \& Haime, 1851)} Figure $1 \mathrm{~F}-\mathrm{H}$

* 1851 Beaumontia guerangeri; Milne-Edwards \& Haime, p. 280 , pl. 17 , fig. 1 .

1980 Praemichelinia guerangeri guerangeri (Milne-Edwards \& Haime, 1851). - Lafuste \& Plusquellec, pp. 148-162, figs 25 , 26, figs 28-30, figs 32-36, figs $42-44$, pl. 20, figs $1-4$, pl. 21, figs 1, 3, 4, pl. 22, figs 1-8 (see for further synonymy).

1980 Praemichelinia guerangeri cryptospina n. sp. - Lafuste \& Plusquellec, pp. 162-171, fig. 27, figs 46, 47, pl. 21, fig. 2, pl. 22, figs 9, 10.

1985 Michelinia guerangeri (Milne-Edwards \& Haime, 1851). - Birenheide, p. 97, fig. 64.
1988 Praemichelinia guerangeri guerangeri (Milne-Edwards \& Haime, 1851). - Lafuste \& Plusquellec, p. 192.

1999 Praemichelinia n. sp.? e.g. guerangeri guerangeri Milne-Edwards \& Haime, 1851. - Plusquellec \& Jahnke, pp. 439-443, figs 3-5, pl. 1, figs 5-7.

Holotype and diagnosis. - See Lafuste \& Plusquellec (1985, p. 148).

Material. - Three isolated coralla with preserved skeleton from the "Emsian/Couvinian" of Colle (Provincia León) (stock No. 801D, 1110D and 1111D).

Colle is a small village on regional road LE-3143, approximately $5 \mathrm{~km}$ east of Boñar. On the slope of the hill where the Colle church is situated are outcrops of upper Emsian shales and marlstones with intercalated limestones that have been well-known since the nineteenth century for the quality and wealth of their fossil content. Modern descriptions of this locality are given in Fernández et al. (1995, p. 43), García-Alcalde (1999), and Fernández et al. (in press). The material probably comes from this locality.

Description. - The coralla are cerioid, irregularly spherical, and $22-28 \mathrm{~mm}$ in diameter. The substratum of corallum $801 \mathrm{D}$ was a brachiopod valve. In the two other specimens the substratum is unknown. The corallites rise from the substratum in a fan-like pattern. The longest corallites, which reach almost from the oral surface of the corallum to the substratum, are $17-20 \mathrm{~mm}$ long in coralla $1110 \mathrm{D}$ and $1111 \mathrm{D}$, and about $10 \mathrm{~mm}$ long in corallum 801D.

The outer (aboral) surfaces of the coralla show well developed growth wrinkles. Furthermore, they show fine rows of points or fine stripes that are longitudinally oriented. There are 3-6 rows of points or stripes to $1 \mathrm{~mm}$ vertical distance.

The calices are polygonal or rounded polygonal. The large calices in coralla $801 \mathrm{D}$ and $1111 \mathrm{D}$ are $3.8-4.0 \mathrm{~mm}$ in diameter, and 4.0-4.5 mm in corallum 1110D. Between the large calices there also occur some small calices, the maximum diameters of which vary between 1 and $3.5 \mathrm{~mm}$.

Longitudinal sections (produced by erosion) show that the calices are about $2-3 \mathrm{~mm}$ in depth. The common wall between the corallites is $0.1-0.5 \mathrm{~mm}$ (mostly about $0.2 \mathrm{~mm}$ ) thick. All horizontal skeletal elements are convex and bubble-like or inverse plate-like. Incomplete horizontal skeletal elements (= tabellae) and complete horizontal skeletal elements (= tabulae) have more or less the same frequency. Between 1-3 (mostly 1.5) horizontal skeletal elements occur in a longitudinal distance of $1 \mathrm{~mm}$.

Septal spines occur frequently. They are very small, nodule-like, and reach a maximum of $0.1 \mathrm{~mm}$ into the lumen of the corallite. No mural pores were observed. 
Remarks. - The Spanish material matches very well with the description of Praemichelinia guerangeri (Milne-Edwards \& Haime, 1851) by Lafuste \& Plusquellec (1980), and with the description of Michelinia guerangeri (Milne-Edwards \& Haime, 1851) by Birenheide (1985). Lafuste \& Plusquellec (1980) describe beside the typical $P$. guerangeri guerangeri as other subspecies of Praemichelinia guerangeri cryptospina Lafuste \& Plusquellec, 1980 with more weakly developed septal spines. Because it is not possible to make thin sections from the Spanish material, the present author declines to make a subspecific assignment.

Michelinia homofavosa Le Maître, 1952 from the Lower Devonian of Algeria is similar to Michelinia guerangeri (Milne-Edwards \& Haime, 1851), but can be distinguished from the latter by its smaller corallites, the largest of which are only $2.5-3.5 \mathrm{~mm}$ in diameter (Le Maître 1952, pp. 78-79, pl. 9, figs 5-8).

Praemichelinia steli Fernández-Martínez \& Plusquellec, 2006 from the upper Emsian of Colle (Provincia León) is much larger than Michelinia guerangeri. For example, the large corallites in $P$. steli are $6-10 \mathrm{~mm}$ in diameter (Fernández-Martínez \& Plusquellec 2006, p. 47).

Occurrence. - Michelinia guerangeri guerangeri (MilneEdwards \& Haime, 1851) is known from the Pragian of the Armorican Massif in France (Lafuste \& Plusquellec 1980). Michelinia guerangeri cryptospina (Lafuste \& Plusquellec, 1980) occurs in the Lochkovian of the Armorican Massif and the Lower Devonian of Algeria (Lafuste \& Plusquellec 1980). A very closely related form occurs in the lower Emsian of the Kellerwald (Germany). The material described here from the upper Emsian of Northern Spain significantly expands the known stratigraphical and geographical distribution of Michelinia guerangeri.

\section{Subgenus Procteria (Granulidictyum) Schindewolf, 1959}

Type species. - Pleurodictyum granuliferum Schlüter, 1889.

Diagnosis and occurrence. - See Birenheide (1985, p. 101).

\section{Procteria (Granulidictyum) granulifera (Schlüter, 1889)} Figure 1E, I

* 1889 Pleurodictyum granuliferum Schlüter, p. 361, pl. 4, figs 5-8.

1952 Procteria granulifera (Schlüter) emend. Stumm. - Le Maître, pp. 92, 93, pl. 2, figs 13-16.

1983 Procteria (Granulidictyum) granulifera (Schlüter, 1889). - Byra, pp. 50-52, pl. 17, figs 44-46 (see for further synonymy).
1985 Procteria (Granulidictyum) granulifera (Schlüter, 1889). - Birenheide, p. 102, pl. 35, fig. 4.

1999 Procteria (Granulidictyum) granulifera (Schlüter). García-Alcalde \& Soto, pl. 1, figs 1, 2.

Lectotype and diagnosis. - See Byra (1983, pp. 50-51).

Material. - An isolated corallum with preserved skeleton from the "Emsian/Couvinian" of Colle (Provincia León) (stock No. 1516D), and another corallum with preserved skeleton from the upper Eifelian of Polentinos (Provincia Palencia) (stock No. 496D). (More information about the Colle locality is given under Michelinia guerangeri.)

Description of corallum 1516D. - The corallum has a diameter of $17 \mathrm{~mm}$. The aboral surface is slightly concave and shows clear granulation due to rounded nodules of about $0.2 \mathrm{~mm}$ diameter, as is characteristic for the genus Procteria.

The large calices are $4.5-5 \mathrm{~mm}$ in diameter. Small calices, which have $1.5-2 \mathrm{~mm}$ diameters, very frequently occur in the corners of the large calices. The calices are very shallow (may be 1-2 mm depth). On the floor of the calices are irregular nodules of about $0.2-0.3 \mathrm{~mm}$ diameter.

The common wall between the calices is $0.3-1.0 \mathrm{~mm}$ (mostly about $0.5 \mathrm{~mm}$ ) thick. Mural pores are $0.2-0.3 \mathrm{~mm}$ in diameter. The outer margin of the calices shows worn, irregular nodules of about $0.2-0.5 \mathrm{~mm}$ in diameter.

Description of corallum 496D. - The corallum has a diameter of $18 \mathrm{~mm}$. The aboral surface is not visible. The large calices are 4.0-5.0 $\mathrm{mm}$ in diameter. The small calices are very regularly arranged in the corners of the large calices, and have diameters around $1.5 \mathrm{~mm}$.

The common wall between the calices is $0.2-0.5 \mathrm{~mm}$ thick. Mural pores are relatively rare and have diameters between $0.1-0.3 \mathrm{~mm}$. The outer margins of the large calices are slightly undulated due to septal elements.

Remarks. - The Spanish material shows the significant characteristics of Procteria (Granulidictyum) granulifera (Schlüter, 1889). The North American Procteria (Granulidictyum) соrnu (Stumm, 1950) is very similar to Procteria (Granulidictyum) granulifera (Schlüter, 1889), but the large calices of $P$. cornu are only about $3 \mathrm{~mm}$ in diameter (Stumm 1950, p. 213), while the large calices of $P$. granulifera have diameters around $5 \mathrm{~mm}$ (Byra 1983, p. 51). The large calices of the Spanish material are slightly smaller than those of the typical German material of $P$. granulifera, but much larger than those of $P$. cornu. In this way, the Spanish material is similar to the material of Le Maître (1952), in which the calices are also slightly smaller than in the typical German material of $P$. granulifera. The fact that the Spanish material here described extends from the Emsian to the upper Eifelian, but has the characteristics of the 
stratigraphically older African material, supports the classification of the African material with Procteria (Granulidictyum) granulifera (Schlüter, 1889).

Occurrence. - The typical German material of Procteria (Granulidictyum) granulifera (Schlüter, 1889) is widespread in the upper Eifelian of the Western and Eastern Rhenish Massif (Byra 1983; May 1986, p. 30). The material described by Le Maître (1952) from Algeria and Mauritania is somewhat older, as it originates from upper Emsian and lower Eifelian beds.

Furthermore, García-Alcalde \& Soto (1999) figure Procteria (Granulidictyum) granulifera (Schlüter) from the Eifelian/Givetian boundary beds of Aleje (Provincia León). The material described in the present paper from beds of upper Emsian to upper Eifelian age confirms the distribution known hitherto.

\section{Family Cleistoporidae Easton, 1944}

\section{Genus Cleistopora Nicholson, 1888}

Type species. - Michelinia geometrica Milne-Edwards \& Haime, 1851.

Diagnosis and occurrence. - See Birenheide (1985, p. 103).

Remarks. - Similar to the case of Michelinia versus Praemichelinia, Plusquellec (1973) erected the genus Paracleistopora for Cleistopora smythi Le Maître, 1952 based on some microstructural differences. Birenheide (1985, p. 103) considers Paracleistopora Plusquellec, 1973 as a junior synonym of Cleistopora Nicholson, 1888. For reasons discussed above (see Michelinia), the present author follows Birenheide (1985).

\section{Cleistopora smythi Le Maître, 1952}

Figure 1J, K

1875 Michelinia geometrica Edw. \& Haime. - Mallada, p. 83 , pl. 16, fig. 3 .

1952 Cleistopora smythi sp. nov. - Le Maître, pp. 85-87, pl. 3, fig. 16-26.

1973 Paracleistopora smythi Le Maître. - Plusquellec, fig. 1.

1998 Paracleistopora smythi (Le Maître, 1952). - Plusquellec, pl. 1, fig. 12.

Type material and diagnosis. - See Le Maître (1952, pp. 85-86).

Material. - An isolated corallum with preserved skeleton from the "Emsian/Couvinian" of Las Peñotas (Provincia León) (stock No. 41D).

Description. - The corallum is very flat (3-6 mm thick) and slightly convex. It is a fragment with a maximum length of $24 \mathrm{~mm}$. A holotheca with growth wrinkles is developed on the aboral surface.

All calices are hexagonal and have a similar size: 6-8 $\mathrm{mm}$ diameter, mostly $6.5-7.5 \mathrm{~mm}$. The calices are 1.5-2 mm deep. The floor of the calices is even, but shows many short septal spines of about $0.1-0.5 \mathrm{~mm}$ diameter with nodule-like appearances.

The common wall between the calices is $0.6-1.0 \mathrm{~mm}$ (mostly about $0.5 \mathrm{~mm}$ ) thick. It shows $0.6-1.0 \mathrm{~mm}$ thick broad septal ridges that form tooth-like elevations. A longitudinal section shows that the basal parts of the corallites are filled by a spongy mass of septal elements.

Remarks. - The Lower Devonian species Cleistopora geometrica (Milne-Edwards \& Haime, 1851) can be distinguished easily from Cleistopora smythi Le Maître, 1952 by its smaller size (4-5 mm corallite diameter) (Plusquellec 1976, pp. 183-187, pl. 38, figs 1-5; Birenheide 1985, p. 103 , pl. 36, fig. 3 ).

Mallada (1875) describes Michelinia geometrica Milne-Edwards \& Haime, 1851 from Las Peñotas. However, the fact that the material described by Mallada (1875) has corallite diameters between 5 and $7 \mathrm{~mm}$ excludes it from the true Cleistopora geometrica (Milne-Edwards \& Haime, 1851), and proves its identity with the material described in the present paper as Cleistopora smythi Le Maître, 1952. It is possible that the specimen described here is identical to the material cited by Mallada (1875) from Las Peñotas.

Occurrence. - Cleistopora smythi Le Maître, 1952 is known from the upper Emsian of Algeria and the Armorican Massif in France (Boumendjel et al. 1997, p. 98; Plusquellec 1998). The material described in the present paper from the Emsian/Eifelian of northern Spain significantly expands the known geographical distribution of Cleistopora smythi.

\section{Conclusions}

The descriptions given here of five different species of Micheliniidae and Cleistoporidae from different parts of Spain significantly contribute to the knowledge of this group, and allow several important conclusions to be drawn:

Michelinia guerangeri (Milne-Edwards \& Haime, 1851) and Cleistopora smythi Le Maître, 1952 are described from Spain for the first time. Pleurodictyum elisabetae sp. nov. is totally new. This diversity of species 
in such a limited collection allows us to expect the total diversity of Devonian Micheliniidae and Cleistoporidae in Spain to be much higher.

The biogeographical relationships between Spain, France, Germany, and northern Africa are very close. Spain shares four species with northern Africa, three with Germany, and three with France. With the exception of Pleurodictyum elisabetae sp. nov. none of the species show any closer relationship to Asian tabulate corals. These observations are consistent with the assigning of central and northern Spain to the Ibarmaghian Domain of the North Gondwana Province by Plusquellec et al. (1997, p. 124) and Plusquellec \& Hladil (2001, p. 43).

It is remarkable that the Spanish Micheliniidae and Cleistoporidae show very few relationships to Asia, as the close relationships of other groups of Spanish tabulate corals to Asia are well known - e.g. in the favositids (Oekentorp 1975) and in the thamnoporids (May 1993c, 1995). Perhaps the Micheliniidae and Cleistoporidae had a higher degree of endemicity than other groups of tabulate corals. A similar situation is known from the Auloporida of Poland (Zapalski 2005).

These Micheliniidae and Cleistoporidae have only very limited biostratigraphical value. This may be demonstrated by two examples: In the Armorican Massif (France) Michelinia guerangeri (Milne-Edwards \& Haime, 1851) is restricted to the Lochkovian and Pragian, but in northern Spain it occurs in beds of upper Emsian age. García-Alcalde \& Soto (1999) use Procteria (Granulidictyum) granulifera (Schlüter, 1889) as an index fossil for the Eifelian/Givetian boundary, but this species also occurs in the upper Emsian beds of the same region.

The Micheliniidae and Cleistoporidae have their highest frequency and diversity in Spain during the Emsian and Eifelian. However, even within this time-span, they are only a subordinate group of tabulate corals. For comparison, ten species of favositids (Oekentorp 1975), six species of thamnoporids (May 1993c), four species of the genus Parastriatopora (May 1993c, May 2005, Tourneur \& Fernández-Martínez 1991), two species of the genus Caliapora (Fernández-Martínez \& Tourneur 1993) and one heliolitid species (Fernández-Martínez 1999) are known from the Emsian and Eifelian of the Cantabrian Mountains.

\section{Acknowledgements}

Without the support of the following persons this investigation would not have been possible: Antonio Perejón Rincon (Universidad Complutense Madrid) proposed that I investigate the collections of the Museo Geominero. Isabel Rábano Gutiérrez del Arroyo, the director of the Museo Geominero, permitted and supported this research. Silvia Menéndez Carrasco, the custodian of the palaeontology collections of the Museo Geominero, sup- ported my research in various ways. Arnošt Galle (Prague) and Klemens Oekentorp (Münster) helped me to seek the original publication of Pleurodictyum? parvum Dubatolova. Peter Britain (Munich) proofread the English of the manuscript. Mikołaj K. Zapalski (Faculty of Geology, Warsaw University, Poland) and Bruno Mistiaen (Laboratoire de Paleontologie stratigraphique UMR 8014 du CNRS, Lille) reviewed the article and gave very helpful suggestions. For all of this support I am very thankful. This article is a contribution to the IGCP 499 "Devonian land-sea interaction: evolution of ecosystems and climate".

\section{References}

BIRENHEIDE, R. 1985. Chaetetida und tabulate Korallen des Devon. Leitfossilien 3, 1-249.

Birenheide, R., Plusquellec, Y. \& Tourneur, F. 1989. Neubeschreibung des Originalmaterials von Pleurodictyum petrii Maurer 1874, der Typus-Art von Petridictyum Schindewolf 1958 (Tabulata; Unter-Devon, Rheinisches Schiefergebirge). Neues Jahrbuch für Geologie und Paläontologie Monatshefte 1989(6), 356-374.

BotQuelen, A. 2003. Impact des variations eustatiques sur les assemblages benthiques a brachiopodes: l'Ordovicien sarde et le Devonien ibero-armoricain. 325 pp. Thèse de doctorat, Universite de Bretagne Occidentale, Brest.

Boumendjel, K., Brice, D., Copper, P., Gourvennec, R., Jahnke, H., Lardeux, H., Le Menn, J., Mélou, M., Morzadec, P., Paris, F., Plusquellec, Y. \& Racheboeuf, P. 1997. Les faunes du Dévonien de l'Ougarta (Sahara occidental, Algérie). Annales de la Société Géologique du Nord 5, $2^{\text {ème }}$ série(2), 89-111.

BYRA, H. 1983. Revision der von Cl. Schlüter (1880-1889) beschriebenen Chaetetida und Tabulata aus dem Rheinischen Devon. Courier Forschungsinstitut Senckenberg 59, 1-127.

Clarke, J.M. 1908. The beginnings of dependent life. New York State Museum Bulletin 121, 146-196.

Collin, L. 1912. Étude de la région dévonienne occidentale du Finistère. 470 pp. Thèse, Brest.

Crousilles, M., Dixsaut, C. \& Lafuste, J. 1978. Données nouvelles sur les calcaires du Dévonien inférieur de la Province de Cordoue (Espagne). Comptes Rendus hebdomadaires des séances de l'Academie des Sciences, Série D 286, 507-509.

Dubatolov, V.N. \& Dubatolova, Y.A. 1969. Podklass Tabulata - Tabuljaty, 34-43. In ModZALevsKAJA, E.A. (ed.) Polevoj atlas silurijskoj, devonskoj y rannekamennougol'noj fauny dal'nego vostoka. Izadatelstvo Nedra, Moskva.

EASTON, W.H. 1944. Corals from the Chouteau and related formations of the Mississipi Valley region. Report of the Geological Survey of Illinois 97, 1-93.

EHRENBERG, C.G. 1834. Beiträge zur physiologischen Kenntniß der Corallenthiere im allgemeinen, und besonders des rothen Meeres, nebst einem Versuche zur physiologischen Systematik derselben. Abhandlungen der Köninglichen Akademie der Wissenschaften in Berlin 1832, 225-380.

FERnÁNDEZ, L.P., FERnÁNDEZ-MARTíneZ, E., MÉNDEZ-BEDIA, I., RodríguEZ, S. \& Soto, F. 1995. VII International Symposium on Fossil Cnidaria and Porifera, Field Trip A, September 
5-11, 1995: Devonian and Carboniferous reefal facies from the Cantabrian Zone (NW Spain). 76 pp. Madrid.

FernándeZ, L.P., Nose, M., FernándeZ-Martínez, E., Méndez-Bedia, I., Schröder, S. \& Soto, F. In press. Reefal and mud mound facies development in the Lower Devonian La Vid Group at the Colle outcrops (León province, Cantabrian Zone, NW Spain). Facies (online first), http://www.springerlink.com (published online 14 March 2006).

FernándeZ-MartíneZ, E. 1999. Heliolitidae (Cnidaria, Tabulata) del Devónico de la Cordillera Cantábrica (NW de España). Trabajos de Geología 21 (Volumen Homenaje a J. Truyols), 97-110.

FERnÁNDEZ-MARTíneZ, E. \& Plusquellec, Y. 2006. A new species of Praemichelinia (Tabulata) from the Emsian (Lower Devonian) of Colle (Cantabrian Mountains, NW Spain) and the occurrence of solenia-like pores in the genus. Revista Española de Paleontología 21(1), 43-59.

Fernández-Martínez, E. \& Tourneur, F. 1993. El genero Caliapora (Tabulata) en el Devónico de la Cordillera Cantábrica (NW de España). Revista Española de Paleontología $n^{o}$ extraordinario, $58-70$.

FuChS, G. \& PlusQuellec, Y. 1982. Pleurodictyum problematicum Goldfuss 1829 (Tabulata, Dévonien). Statut, morphologie, ontogénie. Geologica et Palaeontologica 15, 1-26.

García-AlCALDE, J.L. 1999. Terebratúlidos (Braquiópodos) del Emsiense superior de Colle (Sabero, León, N. de España). Trabajos de Geología 21 (Volumen Homenaje a J. Truyols), 159-176.

García-AlCALDE, J.L. \& Soto, F. 1999. El límite Eifeliense/Givetiense (Devónico Medio) en la Cordillera Cantábrica ( $\mathrm{N}$ de España). Revista Española de Paleontología, Homenaje al Prof. J. Truyols, no. extraordinario, 43-56.

GoldFuss, G.A. 1826-1833. Petrefacta Germaniae. Erster Theil. 12 pp. + 252 pp. Düsseldorf.

HERNÁNDEZ SAMPElAyO, P. 1948. Coralarios devonianos del Sahara Español. Boletín del Instituto Geológico y Minero de España 61, 1-45.

HiLl, D. 1981. Rugosa and Tabulata, i-xl + 1-672. In TeICHERT, C. (ed.) Treatise on Invertebrate Paleontology, Part F, Coelenterata, Suppl. 1. The Geological Society of America and University of Kansas, Lawrence.

Koninck, L.G. DE 1841-1844. Déscription des animaux fossiles qui se trouvent dans le terrain Carbonifère de Belgique. 650 pp. Liège.

Lafuste, J., Fernández-Martínez, E. \& Tourneur, F. 1992. Parastriatopora (Tabulata) de las calizas del Lorito (Devónico inferior, Provincia de Córdoba): Morfología y microestructura. Revista Española de Paleontología 7(1), 3-12.

Lafuste, J. \& Plusquellec, Y. 1980. Les Polypiers - Tabulata, 143-173. In PlusQuellec, Y. (ed.) Les schistes et calcaires de l'Armorique (Devonien inférieur, Massif Armoricain). Mémoires de la Société géologique et minéralogique de Bretagne 23.

Lafuste, J. \& Plusquellec, Y. 1985. Structure et microstructure de quelques Micheliniidae et Michelinimorphes (Tabulata paléozoïques). Bulletin du Muséum national d'Histoire naturelle, $4^{e}$ série, 7, C(1), 13-55.

LAfuste, J. \& Plusquellec, Y. 1988. Révision des Beaumontia décrits par Milne-Edwards et Haime (Tabulata; Dévonien, Carbonifère). Bulletin du Muséum national d'Histoire naturelle, $4^{e}$ série, 10, C(3), 179-193.

Lafuste, J., Plusquellec, Y. \& Soto, F. 1993. Coexistence de lamelles et de microlamelles dans le sclérenchyme de "Ligulodictyum" Plusquellec, 1973 (Tabulata, Dévonien du Nord-Gondwana). Courier Forschungsinstitut Senckenberg 164, 329-337.

LE MAîTRE, D. 1952. La faune du Dévonien inférieur et moyen de la Saoura et des abords de l'Erg el Djemel (Sud-Oranais). Materiaux pour la carte géologique de l'Algérie, $1^{\text {ère }}$ Série Paléontologie 12, 1-171.

Le Menn, J., Plusquellec, Y., Morzadec, P. \& Lardeux, H. 1976. Incursion hercynienne dans les faunes rhénanes du Dévonien inférieur de la Rade de Brest (Massif armoricain). Palaeontographica, Abt. A 153(1-3), 1-61.

MalladA, L. 1875. Sinopsis de las especies fósiles que se han encontrado en España. (Introduccion \& Terreno paleozoico.) Boletín de la Comision del Mapa Geológico de España 2, $1-160$.

MAY, A. 1986. Biostratigraphische Untersuchungen im MittelDevon des Nordwest-Sauerlandes (Rheinisches Schiefergebirge). Dortmunder Beiträge zur Landeskunde, Naturwissenschaftliche Mitteilungen 20, 23-55.

MAY, A. 1993a. Korallen aus dem höheren Eifelium und unteren Givetium (Devon) des nordwestlichen Sauerlandes (Rheinisches Schiefergebirge). Teil I: Tabulate Korallen. Palaeontographica, Abt. A 227, 87-224.

MAY, A. 1993b. Korallen aus dem höheren Eifelium und unteren Givetium (Devon) des nordwestlichen Sauerlandes (Rheinisches Schiefergebirge). Teil II: Rugose Korallen, Chaetetiden und spezielle Themen. Palaeontographica, Abt. A 228, 1-103.

MAY, A. 1993c. Thamnopora und verwandte ästige tabulate Korallen aus dem Emsium bis Unter-Eifelium von Asturien (Devon; Nord-Spanien). Geologica et Palaeontologica 27, 73-101.

MAY, A. 1995. Thamnopora (Anthozoa: Tabulata) aus dem Givetium bis Frasnium von Asturien (Devon; Nord-Spanien). Münstersche Forschungen zur Geologie und Paläontologie 77, 479-491.

May, A. 2005. A new Parastriatopora species (Anthozoa, Tabulata) from the Lower Devonian of Colle (Spain, Cantabrian Mountains). Bulletin of Geosciences 80(4), 287-290.

Milne-Edwards, H. \& HAime, J. 1850. A monograph of the British fossil corals. First part. Introduction; corals from the Tertiary and Cretaceous Formations. Monographs of the Palaeontographical Society London 3(2) 7, i-lxxxv + 1-72.

Milne-Edwards, H. \& Haime, J. 1851. Monographie des Polypiers fossiles des terrains paléozoiques. Archives $d u \mathrm{Mu}$ séum d'Histoire Naturelle 5, 1-502.

NichOLSON, H.A. 1888. On the structure of Cleistopora (Michelinia) geometrica Edwards \& Haime sp. Geological Magazine 3(5), 150-152.

OEKENTORP, K. 1972. Sekundärstrukturen bei paläozoischen Madreporaria. Münstersche Forschungen zur Geologie und Paläontologie 24, 35-108.

OEKENTORP, K. 1975. Beschreibung und Systematik devonischer Favositidae Asturiens und Betrachtungen zur Biogeographie nordspanischer Korallenfaunen. Münstersche Forschungen zur Geologie und Paläontologie 37, 1-129. 
OeKentorP, K. 1980. Aragonit und Diagenese bei jungpaläozischen Korallen. Münstersche Forschungen zur Geologie und Paläontologie 52, 119-239.

OEKENTORP, K. 2001. Review on diagenetic microstructures in fossil corals - a controversial discussion. Bulletin of the Tohoku University Museum 1, 193-209.

OekentorP, K. \& SchröDer, S. 2001. Korallen (Rugosa; Tabulata) aus dem Paläozoikum des SW Sultan Dag, Türkei, 369-381. In WEISS, R.H. (ed.) Contributions to geology and palaeontology of Gondwana, in honour of Helmut Wopfner. Cologne.

PlusQuellec, Y. 1965. Le genre Pleurodictyum Goldfuss et genres morphologiquement voisins du Dévonien du synclinorium médian armoricain. Travaux du Laboratoire de Géologie du College scientifique Universitaire de Brest, Paléontologie, 1-90.

Plusquellec, Y. 1970. De quelques Procteria (Tabulata) devoniens. Société géologique et minéralogique de Bretagne, Bulletin, série C 1(2), 59-70.

Plusquellec, Y. 1973. Précisions sur la systématique de quelques Tabulés pleurodictyformes. Comptes Rendus hebdomadaires des séances de l'Academie des Sciences, Série D 277, 153-156.

Plusquellec, Y. 1976. Les Polypiers - Tabulata, 183-215. In LARDEUX, H. (ed.) Les schistes et calcaires eodevoniens de Saint-Céneré (Massif Armoricain, France), Mémoires de la Société géologique et minéralogique de Bretagne 19.

Plusquellec, Y. 1993. Un Tabulé pleurodictyforme "biface" Procterodictyum n. gen. (Emsien du Nord Gondwana). Geologica et Palaeontologica 27, 103-121.

PlusquelleC, Y. 1998. Pleurodictyidae de l'Emsien supérieur des Monts d'Ougarta (Algéria). Annales de la Société Géologique du Nord 6 (2 $2^{\text {ème }}$ série), 5-23.

Plusquellec, Y., Boumendjel, K., Morzadec, P. \& Paris, F. 1997. Les faunes Dévoniennes d'Ougarta dans la paléogéographie des régions Maghrébo-Européennes. Annales de la Société Géologique du Nord 5 (2 $2^{\text {ème }}$ série), 123-128.

Plusquellec, Y. \& HLADIL, J. 2001. Tabulate corals of Ibar- maghian affinities in the Upper Emsian of Bohemia. Geologica et Palaeontologica 35, 31-51.

PlusquelleC, Y. \& JAHNKe, H. 1999. Les tabulés de l'Erbslochgrauwacke (Emsien inférieur du Kellerwald) et le probleme des affinités paleogeographiques de l'allochthone "Giessen-Harz". Abhandlungen der Geologischen Bundesanstalt $54,435-451$.

Plusquellec, Y., Tourneur, F. \& Lafuste, J. 1993. Saouraepora nouveau genre de Micheliniidae (Tabulata) du Dévonien du Nord Gondwana et du Carbonifère d'Amérique du Nord. Palaeontographica, Abt. A 227(1/3), 1-86.

SCHINDEWOLF, O.H. 1959. Würmer und Korallen als Synöken. Zur Kenntnis der Systeme Aspidosiphon/Heteropsammia und Hicetes/Pleurodictyum. Abhandlungen der Akademie der Wissenschaften und Literatur, mathematisch-naturwissenschaftliche Klasse 1958(6), 259-328.

SCHLÜTER, C. 1889. Anthozoen des rheinischen Mitteldevon. Abhandlungen zur geologischen Special-Karte von Preussen und den thüringischen Staaten 8(4), x + 259-465.

Stumm, E.C. 1950. Corals of the Devonian Traverse Group of Michigan. Part III, Antholites, Pleurodictyum, and Procteria. Contributions of the Museum of Paleontology, University of Michigan 8(8), 205-220.

Tourneur, F. \& FernándeZ-MartíneZ, E. 1991. Parastriatopora cantabrica, nueva especie de tabulado del Devónico inferior (Emsiense) de la Cordillera Cantábrica (NO de España). Revista Española de Paleontología 6(1), 3-19.

WAAgen, W.H. \& WentZel, J. 1886. Salt Range fossils, vol. 1, Productus limestone fossils; 6, Coelenterata. Memoirs of the Geological Survey of India, Palaeontologia indica 13, 835-924.

WEDEKIND, R. 1937. Einführung in die Grundlagen der historischen Geologie. II. Mikrobiostratigraphie: Die Korallen- und Foraminiferenzeit, 1-136. Stuttgart.

ZAPALSKI, M.K. 2005. A new species of Tabulata from the Emsian of the Holy Cross Mts., Poland. Neues Jahrbuch für Geologie und Paläontologie, Monatshefte 2005(4), 248-256. 